\title{
UCD techniques applied to the design of interfaces for integration between Expert System and GIS to define the directive of transmission lines
}

\author{
Renan Daros $^{\mathrm{a}, *}$, Luciene Stamato Delazari ${ }^{\mathrm{b}}$, Daniel Rodrigues dos Santos ${ }^{\mathrm{b}}$, Ana C. Aoki Lopes ${ }^{\mathrm{c}}$, \\ José E. Gonçalves ${ }^{\mathrm{d}}$, Leonardo Ercolin Filho ${ }^{\mathrm{b}}$, Tiago L. Rodrigues ${ }^{\mathrm{b}}$, Tony V. Moreira Sampaio ${ }^{\mathrm{b}}$ \\ ${ }^{a}$ Graduate Program in Geodetic Sciences, Federal University of Paraná, Curitiba, Paraná, Brazil; renan.daros@ufpr.br \\ ${ }^{b}$ Department of Geomatics, Federal University of Paraná,Curitiba, Paraná,Brazil; luciene@ufpr.br, danielsantos@ufpr.br, \\ leonardo.ercolin@ufpr.br,tiagorodrigues@ufpr.br,tonysampaio@ufpr.br \\ ${ }^{c}$ Copel Generation and Transmission S. A., Curitiba, Paraná, Brazil; ana.aoki@copel.com \\ d Paraná Meteorological System - Simepar, Curitiba, Paraná, Brazil; jose.eduardo@simepar.br
}

Keywords: Expert Systems, UCD, GIS

\begin{abstract}
:
This paper presents part of the results of the R\&D project PD-06491-0353 / 2014 " Development of an automatic method for optimized estimation of the direction of the tracing of power transmission lines using an inverse dynamic programming model and meteorological variables " developed by the Federal University of Paraná (UFPR) and Paraná Meteorological System (SIMEPAR) for Copel Generation and Transmission S.A. within the scope of the Electric Sector Research and Technological Development Program regulated by the National Electric Energy Agency (ANEEL).
\end{abstract}

Brazil currently has $160,859.05 \mathrm{~km}$ of installed transmission lines (4x the distance around the Earth at the Equator), connecting 5,570 municipalities, hydroelectric plants, substations, industrial parks, and power plants. In 2020, 6,159.34 $\mathrm{km}$ of transmission lines were built, which is continuously expanding as a result of the country's economic and population growth. To ensure the existence of energy resources and guarantee future demands, it is necessary to build new installations of electricity transmission lines and substations throughout the country.

There are many challenges to be overcome at the stage of the transmission line layout study for construction clearance. This is because the study may include places close to indigenous lands, airports, rural settlements, conservation units, and areas of urban occupation. In addition to this challenge being extremely complex, there are other obstacles that professionals working with the design of a transmission line directive must take into account. The planning process for tracing a transmission line guideline involves the study of several geographic variables, which is possible to categorized into three types of criteria: social, environmental, and economic.

As it is a project that depends on several geographic variables, it is possible to use the Analytic Hierarchy Process (AHP) method, a method that helps professionals in making complex decisions. The AHP method helps to define the hierarchy between geographic variables that are the object of study and the weights that define their level of importance. With the hierarchy defined between the layers and their level of importance, spatial operations are performed in a GIS, obtaining the so-called lowest cost path, representing the optimal solution for the installation of a transmission line.

Throughout the process, there was a need to create a tool with a graphical and interactive interface to help specialists who work to choose the best route for the construction of a transmission line. The development of a computational tool speeds up the decision-making process by specialists and makes scenario simulation feasible. For this tool, we opted for the integration of a Geographic Information System (GIS) and an Expert System (ES).

An ES is a computer system that emulates the decision-making capability of an expert in an area of knowledge or application. ES is characterized by: a set of rules (if/else) that make up an expert's knowledge base; and the inference engine that allows conclusions from facts (input data) and the knowledge base (processing) performed through the construction of logical relationships.

To help professionals who work with the planning of transmission lines, this research focuses on the development of a computer solution with a user-centered design process (UCD). The UCD encompasses techniques, processes, and procedures for designing interfaces aimed at usability, and especially the philosophy of putting the user in the center of attention. The UCD process can be divided into four steps.

In the first step, the context of use of the solution is understood, understanding the users of the process, identifying objectives, tasks, methods, techniques, limitations and needs. 
In defining the parties interested in the solution, two terminologies are adopted: Customer and User. The customer is the one who represents the parties interested in the service or purchase of a product, in this case, we adopt as Customers the company Paraná Electric Power Company (COPEL) and the Federal University of Paraná (UFPR). Users, on the other hand, are professionals who will use the interfaces of the computing solution to be developed. Users can still receive two ratings: Primary users are the specialists who will interact with the tool; Secondary users, professionals who will make use of the products derived from the solution, Managers who authorize the financing of research, and researchers who are interested in seeing their methodologies applied computationally. The different types of users are termed as stakeholders.

In the initial understanding of users, the technique of questionnaires was applied, seeking to know about the training of specialists who work with transmission line projects and to know, individually, the criteria adopted and their level of importance. Table 1 shows the professional training of the specialists, the choice in the comparison between Proximity to aerodromes vs. Proximity to railways, and the choice of the level of importance with values from 1 to 9.

\begin{tabular}{|c|c|c|c|c|}
\hline User & U1 & U2 & U3 & U4 \\
\hline Formation & $\begin{array}{c}\text { Electromechanical } \\
\text { Project } \\
\text { Engineering }\end{array}$ & $\begin{array}{c}\text { Transmission } \\
\text { Line } \\
\text { Engineering }\end{array}$ & $\begin{array}{c}\text { Cartographic } \\
\text { Engineering }\end{array}$ & $\begin{array}{c}\text { Contract } \\
\text { Management and } \\
\text { Transmission } \\
\text { Line Projects }\end{array}$ \\
\hline $\begin{array}{c}\text { Aerodromes } \\
\text { x Railways }\end{array}$ & $\begin{array}{c}\text { Proximity to } \\
\text { aerodromes }\end{array}$ & $\begin{array}{c}\text { Proximity to } \\
\text { railroads }\end{array}$ & $\begin{array}{c}\text { Proximity to } \\
\text { railroads }\end{array}$ & $\begin{array}{c}\text { Proximity to } \\
\text { aerodromes }\end{array}$ \\
\hline Importance & 9 & 9 & 1 & 7 \\
\hline
\end{tabular}

Table 1. Choice of participating users and degree of importance.

Then, the criteria were analyzed individually, that is, all the criteria were compared to each other to establish their relative importance. Table 2 shows the discrepancy in the answers regarding the Passage of a Transmission Line for a rural property, with users as answer options: Mandatory Passage, Favorable Passage, Indifferent, Avoid Passage and There must be no pass.

\begin{tabular}{|c|c|c|c|c|}
\hline User & $\mathrm{U} 1$ & $\mathrm{U} 2$ & $\mathrm{U} 3$ & $\mathrm{U} 4$ \\
\hline $\begin{array}{c}\text { Passing } \\
\text { through rural } \\
\text { properties }\end{array}$ & Indifferent & $\begin{array}{c}\text { Obligatory } \\
\text { passage }\end{array}$ & $\begin{array}{c}\text { Favorable } \\
\text { passage }\end{array}$ & avoid passage \\
\hline
\end{tabular}

Table 2. Choice of users regarding the passage through rural properties.

The second stage consists of specifying the user's requirements, and the interview technique will be used, in order to better understand the user, collect their experiences with tools in a GIS environment, their difficulties, needs, goals, and desires. To convert user studies into the solution development process, the second stage will use the techniques of Personas and Empathy Maps.

The third step refers to the production of design solutions that meet user requirements. At this stage, it is intended to adopt the Prototyping technique, in order to materialize the project ideas and validate the information collected with the user, allowing tests prior to the construction of the solution.

In the last step, the objective is to evaluate the project solutions in relation to the requirements. Unlike software testing, proposed in Software Engineering, the Human Computer Interaction Assessment aims to verify if the system supports the user to achieve his goals. The evaluation is divided into Inspection Tests and Usability Tests.

In the inspection test, the Heuristic Evaluation, created by Jakob Nielsen, will be used to collect information regarding usability issues and to improve interactions and user experience. In Usability Testing, the objective is to test the interaction of the end user with the system.

The end user of the application will have a fundamental role in the development of the computational solution integrating SE and GIS, as through it will be possible to develop a computational solution that adopts the concepts of User Experience (UX) and Usability rules, creating an interface that provides an experience enjoyable, easy to learn, protection against user errors and intuitive interaction by creating affordances.

\section{ACKNOWLEDGMENT}

The authors thank CNPq for the fellowship grant, process 310312/2017-5. 